\title{
Co znalazła, a co zgubiła powieść w eseju Thomasa Pavla?
}

\section{What Has the Novel Lost and Gained in Thomas Pavel's Essay?}

Thomas Pavel dokonał rzeczy wydawałoby się zasadniczo niemożliwej: przedstawił zwartą, konsekwentną i logiczną historię powieści europejskiej na trzydziestu stronach. Za dokonywanie rzeczy niemożliwych płaci się jednak pewną cenę, często cenę wysoką. Spróbuję ocenić artykuł Pavla, zestawiając ze sobą cechy pozytywne owego, wydawałoby się, „cudu”, tego dokonania rzeczy niemożliwej, i jego cechy negatywne, czyli cenę, jaką przyszło zapłacić przy realizacji tego wyjątkowego zadania.

Spośród cech pozytywnych należałoby wymienić dobrą organizację całego wywodu, który jest logiczny, spójny i konsekwentny w ramach przyjętej przez autora tekstu zasady: ewolucję powieści śledzi on szlakiem relacji bohatera do świata przedstawionego, będącego w opozycji do protagonisty, a relację przedstawia, odmierzając jej stopień zaangażowania po stronie idealizującej wizji świata zewnętrznego lub przeciwnie, antyidealizującej.

W tak określonym paradygmacie rozwoju powieści Thomas Pavel omawia historyczno-literacki rozwój powieści bardzo sprawnie. W przedstawionym przez niego porządku następujących po sobie etapów równowaga między zachodnią i wschodnią, południową i północną Europą jest względnie dobra, chociaż ciągle daleka od perfekcji ${ }^{1}$; w porównaniu z najczęściej występującym brakiem równowagi wydaje się przykładem pozytywnym.

Prezentacja kolejnych odsłon dialogu między idealizacją a potępieniem ludzkich słabości, stanowiącego w ujęciu Pavla szkielet i siłę napędową powieści europejskiej, jest klarowna, ogarniająca bardzo duży materiał literacki i porządkująca; mogłaby, jak sądzę, z powodzeniem pełnić funkcję dydaktycznego

${ }^{1}$ Perfekcję taką osiąga na przykład Harold B. Segel w swojej antologii The Baroque Poem: A Comparative Survey, będącej ciągle niedoścignionym wzorem prawdziwej równowagi w prezentacji literatury z każdego regionu Europy. 
wspomagania wykładów z historii literatury europejskiej. Zwłaszcza że studenci stale poszukują takiego rodzaju przeciwwagi dla zbyt specjalistycznie i szczegółowo przedstawianej historii literatury czy procesów historycznoliterackich.

Po drugiej stronie, czyli po stronie cech negatywnych, wymienić można następujące słabości i błędy².

Prezentacja ewolucji powieści przez Thomasa Pavla przez zbyt chyba intensywne skupienie się autora publikacji na moralnej wymowie utworów i dosyć jednak schematycznym podziale na idealizujące i antyidealizujące tendencje jako na główny miernik rozwoju staje się momentami zbyt uproszczona i niewystarczająco uwzględnia znaczenie formy w całej jej złożoności. Przykładem takiego właśnie zbyt uproszczonego i nie dosyć czujnego na znaczenie struktur ironicznych podejścia jest potraktowanie niektórych odmian powieści łotrzykowskiej, w tym szczególnie Żywota Łazika z Tormesu czy arcydzieła Cervantesa, Don Kichota, z całym jego rewolucyjnym nowatorstwem gry ironicznej i autoironicznej. Nie można powiedzieć, że Pavel w ogóle te aspekty wymienionych tu utworów ignoruje, ale zbyt pobieżnie o nich wspomina i nie wchodzi w wystarczającym stopniu w znaczenie takich zabiegów dla dalszego rozwoju systemów narracyjnych. Jest to cena, część ceny, jaką przychodzi mu zapłacić za szybką i atrakcyjną prezentację ewolucji powieści w przyjętym przez siebie paradygmacie.

Ogólnie rzecz biorąc, wywód przedstawiający morfologię historyczną powieści, jak ją nazywa w tytule publikacji autor, jest mimo wszystko nie tylko atrakcyjny, ale i merytorycznie bardzo dobry dopóty, dopóki dotyczy ewolucji powieści do końca XIX wieku, a dokładniej mówiąc, do czasu modernizmu. Od tego momentu zaczyna się słabsza część prezentacji. Szczególnie rażący, w moim przekonaniu, jest w tej części artykułu brak uwzględnienia Josepha Conrada. Jeśli bowiem badacz buduje cały swój paradygmat rozwoju powieści na znaczeniu moralnej wymowy, jak również na dynamicznej relacji między bohaterem a światem, który się mu przeciwstawia, po czym omija Conrada, to mocno destabilizuje spójność swojej argumentacji, swojej koncepcji. Myślę, że znalezienie miejsca na omówienie znaczenia na przykład Jądra ciemności nie tylko oddałoby należne miejsce autorowi tego utworu w historii rozwoju powieści, ale pomogłoby ustawić o wiele sensowniej dalszy ciąg wywodu, prezentującego postmodernistyczny etap, w którym Thomas Pavel chyba nie do końca zauważa, że jego paradygmat przestaje mieć zastosowanie do wielu przykładów powieści XX i XXI wieku, w tym do prozy postmodernistycznej.

2 Ponieważ w dalszej części będę mówić raczej o błędach koncepcyjnych, tutaj chciałabym zwrócić uwagę na nieduży, ale jednak istotny błąd merytoryczny na samym początku tekstu Pavla. Badacz pisze, że „bohaterowie epopei bez reszty przynależą do swoich miast”. O ile bohaterów Iliady, tych oblegających i tych oblężonych, dałoby się, i to z zastrzeżeniami, przypisać do Troi, o tyle inni bohaterowie epopei, nie mówiąc już o bohaterach pieśni epickich (do jakiego miasta miałby przynależeć Roland?), nie przynależeli ani do jednego miasta, ani w ogóle do miast. 
O ile jeszcze udaje się autorowi artykułu w sposób w miarę przekonywający, znaleźć miejsca dla Franza Kafki w swoim modelu rozwoju powieści, odczytując głównych bohaterów Procesu czy Zamku jako przykłady kolejnego etapu $\mathrm{w}$ historii zmagania się protagonisty $\mathrm{z}$ wrogą, coraz też bardziej absurdalną rzeczywistością, o tyle na ostatniej stronie następuje sortowanie autorów w grupy obejmujące zdecydowanie zbyt różne od siebie rodzaje twórczości. Ciągi nazwisk, takie jak Gabriel García Márquez, Georges Perec, Michel Tournier, Thomas Pynchon, Toni Morrison, Salman Rushdie, Umberto Eco, Mario Vargas Llosa, Don DeLillo, sugerujące, że wymienieni autorzy należą do jakiejś jednej całości, podczas gdy zdecydowanie reprezentują różne kategorie, podgatunki, stylistyki i bardzo różne obrazy świata, zupełnie mnie nie przekonują. Jeśli Thomas Pavel poświęca całe szpalty powieści bizantyjskiej, to potem wrzucanie do jednego worka wymienionych przed chwilą powieściopisarzy, opatrzonych jedną linijką komentarza, musi razić.

Zbudowanie historii rozwoju powieści na strukturze „relacja głównego bohatera do otaczającej rzeczywistości, oświetlona idealizującym bądź pesymistycznym reflektorem" funkcjonowało świetnie, jak już napomknęłam, na przykładach wziętych z literatury pisanej do końca XIX wieku. Byłoby dobrze, gdyby na tym punkcie autor artykułu się zatrzymał. Natomiast próba zastosowania tego paradygmatu do powieści o zupełnie innej koncepcji literackiego tworzenia świata przedstawionego oraz o radykalnie innym systemie narracji nie może się udać. Weźmy na przykład powieść Pedro Paramo Juana Rulfa, w której mamy do czynienia z całkowicie sfragmentaryzowaną narracją i rzeczywistością przedstawioną. Narracja prowadzona jest przez połączenie mnóstwa różnych głosów, szeptów, ech, opisujących mozaikowo przedstawiane obrazy, cienie, odbicia. Cała ta struktura jest znakomicie spójna i przekonywająca, ale na pewno nie da się „zmierzyć” przystawalnością do paradygmatu morfologii powieści, jakim posługuje się Thomas Pavel. Wymieniłam tu Juana Rulfo, bo jego powieść, Pedro Paramo, jest dla mnie jednym z najlepszych przykładów przełomu, jaki dokonał się w powieści w XX i XXI wieku. Przełomu, po którym ogromna część - chyba większość - powieści buduje obraz świata i przedstawiającą go narrację na mozaice, fragmentaryzacji, na systemach klocków, które czytelnik układa w całość. To już nie bohater zmaga się z otaczającą rzeczywistością, to czytelnik zmaga się z rozbitym obrazem, którego cząstki umieszcza tak, by razem dały odbicie (iluzję odbicia) świata i człowie$\mathrm{ka}$ - tak samo rozbitych jak to zwierciadło, co miało się przechadzać po gościńcu w śnie o mimesis... 